\title{
ADRENALINE AND NORADRENALINE IN CEREBROSPINAL FLUID BY
}

\author{
H. WEIL-MALHERBE and D. W. LIDDELL
}

From Runwell Hospital, Wickford, Essex

The occurrence of adrenaline and noradrenaline in human cerebrospinal fluid (C.S.F.) has not yet been demonstrated. In this note figures for the concentration of these amines in C.S.F. are presented. Since the analysis required a substantial volume of C.S.F., i.e., 15 to $20 \mathrm{ml}$., the estimations were carried out on specimens withdrawn during air encephalography and came from patients with a suspected organic brain lesion. A small group of male schizophrenics was similarly investigated. The concentration of adrenaline and noradrenaline in plasma was determined for comparison in samples withdrawn simultaneously.

\section{Methods}

A sample of 15 to $20 \mathrm{ml}$. C.S.F. was mixed with $5 \mathrm{ml}$. of a solution containing $2 \%$ sodium fluoride and $3 \%$ sodium thiosulphate. The volume was made up to $30 \mathrm{ml}$. with $0.2 \mathrm{M}$ acetate buffer $p \mathrm{H} 8 \cdot 4$, and the mixture adjusted if necessary to $p \mathrm{H} 8.4$ by the addition of a few drops of $0.5 \mathrm{~N}$ sodium carbonate solution. Chromato- graphic purification and condensation with ethylenediamine were carried out according to Weil-Malherbe and Bone (1952), and differential fluorimetry according to Weil-Malherbe and Bone (1953). The collection of blood and the treatment and analysis of plasma have been described in the same papers.

Premedication was only given to a few of the patients in both groups. It consisted of bromide and chloral hydrate, gr. 15 to 20 of each by mouth, one hour before the investigation.

\section{Results}

The results obtained with the non-schizophrenic and schizophrenic groups of patients are shown in Tables I and II respectively. The mean concentrations of adrenaline and noradrenaline in C.S.F. are not significantly different for the two groups. Adrenaline was found in a concentration of $0.9 \mu \mathrm{g}$. $/ 1$. and noradrenaline in a concentration of 2.5 to $3 \mu \mathrm{g}$./l. These concentrations are lower than those found in venous plasma. The concentration of plasma adrenaline is significantly lower in the schizophrenic

TABLE I

THE CONCENTRATION OF ADRENALINE AND NORADRENALINE IN C.S.F. AND PLASMA IN PATIENTS WITH SUSPECIED BRAIN LESIONS

\begin{tabular}{|c|c|c|c|c|c|c|c|c|c|}
\hline \multirow{2}{*}{ No. } & \multirow{2}{*}{ Sex } & \multirow{2}{*}{\multicolumn{2}{|c|}{ Diagnosis }} & \multicolumn{2}{|c|}{ C.S.F. } & \multicolumn{2}{|c|}{ Plasma } & \multicolumn{2}{|c|}{$\frac{\mathrm{CSF}}{\text { Plasma }} \times 100$} \\
\hline & & & & $\begin{array}{c}\text { Adrenaline } \\
\text { (ug./l.) }\end{array}$ & $\begin{array}{l}\text { Noradrena- } \\
\text { line } \\
(\mu \mathrm{g} .1 .)\end{array}$ & $\begin{array}{c}\text { Adrenaline } \\
(\mu \mathrm{g} . / 1 .)\end{array}$ & $\begin{array}{l}\text { Noradrena- } \\
\text { line } \\
\text { (ug./1.) }\end{array}$ & Adrenaline & $\begin{array}{l}\text { Noradrena- } \\
\text { line }\end{array}$ \\
\hline 1 & $\mathrm{~F}$ & Localized cortical atrophy & .. & 0.86 & $3 \cdot 54$ & 1.93 & $8 \cdot 34$ & $44 \cdot 6$ & $42 \cdot 5$ \\
\hline 2 & $\mathbf{M}$ & Epilepsy with temporal focus & . & 0.65 & $1 \cdot 44$ & $2 \cdot 16$ & $8 \cdot 55$ & $30 \cdot 1$ & $16 \cdot 9$ \\
\hline 3 & $\mathbf{M}$ & Post-traumatic epilepsy with t & oral focus & $0 \cdot 63$ & 0.92 & $2 \cdot 35$ & $5 \cdot 70$ & $26 \cdot 8$ & $16 \cdot 1$ \\
\hline 4 & $\mathrm{~F}$ & Psychopath .. & .. & $0 \cdot 25$ & $2 \cdot 86$ & 1.45 & $9 \cdot 50$ & $17 \cdot 2$ & $30 \cdot 1$ \\
\hline 5 & $\mathbf{M}$ & Epilepsy, mental deficiency .. & . & $1 \cdot 21$ & 3.04 & $3 \cdot 22$ & $9 \cdot 40$ & $37 \cdot 6$ & $32 \cdot 4$ \\
\hline 6 & $\mathbf{M}$ & Epilepsy with temporal focus & . & $0 \cdot 87$ & $2 \cdot 32$ & $2 \cdot 28$ & 6.89 & $38 \cdot 2$ & $33 \cdot 7$ \\
\hline 7 & $\mathrm{~F}$ & Presenile dementia & .. & $1 \cdot 15$ & $2 \cdot 87$ & $2 \cdot 80$ & $5 \cdot 30$ & $41 \cdot 1$ & $54 \cdot 1$ \\
\hline 8 & $\mathbf{M}$ & Post-traumatic epilepsy with t & oral focus & $1 \cdot 32$ & 3.03 & $2 \cdot 32$ & $5 \cdot 61$ & $57 \cdot 0$ & $54 \cdot 0$ \\
\hline 9 & $\mathbf{M}$ & Post-traumatic epilepsy with t & oral focus & $1 \cdot 13$ & $2 \cdot 16$ & $2 \cdot 40$ & $5 \cdot 55$ & $47 \cdot 2$ & $39 \cdot 0$ \\
\hline & & Mean & . & 0.90 & $2 \cdot 46$ & $2 \cdot 32$ & $7 \cdot 20$ & $37 \cdot 75$ & $35 \cdot 42$ \\
\hline & & Standard error o & an & $0 \cdot 115$ & $0 \cdot 281$ & $0 \cdot 166$ & 0.583 & 3.942 & $4 \cdot 585$ \\
\hline
\end{tabular}


TABLE II

THE CONCENTRATION OF ADRENALINE AND NORADRENALINE IN C.S.F. AND PLASMA IN MALE SCHIZOPHRENICS

\begin{tabular}{|c|c|c|c|c|c|c|c|}
\hline \multirow{2}{*}{ No. } & \multirow{2}{*}{ Leucotomy } & \multicolumn{2}{|c|}{ C.S.F. } & \multicolumn{2}{|c|}{ Plasma } & \multicolumn{2}{|c|}{$\frac{\text { C.S.F. }}{\text { Plasma }} \times 100$} \\
\hline & & $\begin{array}{l}\text { Adrenaline } \\
(\mu \mathrm{g} . / 1 .)\end{array}$ & $\begin{array}{l}\text { Noradrenaline } \\
(\text { (ug./l.) }\end{array}$ & $\begin{array}{l}\text { Adrenaline } \\
\text { (ug./l.) }\end{array}$ & $\begin{array}{l}\text { Noradrenaline } \\
(\mu g . / 1 .)\end{array}$ & Adrenaline & Noradrenaline \\
\hline 1 & - & 0.51 & $3 \cdot 47$ & $1 \cdot 15$ & $7 \cdot 52$ & $44 \cdot 4$ & $46 \cdot 2$ \\
\hline 2 & - & 0.93 & $2 \cdot 87$ & 1.84 & $7 \cdot 30$ & $50 \cdot 5$ & $39 \cdot 3$ \\
\hline 3 & - & $1 \cdot 57$ & $3 \cdot 72$ & $2 \cdot 53$ & 7.90 & $62 \cdot 5$ & $47 \cdot 2$ \\
\hline 4 & - & 0.96 & $3 \cdot 10$ & $1 \cdot 44$ & 4.45 & $66 \cdot 7$ & $69 \cdot 6$ \\
\hline 5 & - & 0.91 & $2 \cdot 17$ & $1 \cdot 73$ & $4 \cdot 87$ & $52 \cdot 6$ & $44 \cdot 6$ \\
\hline 6 & + & 0.45 & $3 \cdot 64$ & $0 \cdot 81$ & $6 \cdot 8 ?$ & $55 \cdot 5$ & $53 \cdot 4$ \\
\hline 7 & + & 0.85 & $2 \cdot 62$ & 1.41 & 3.85 & $60 \cdot 4$ & $68 \cdot 1)$ \\
\hline \multirow[t]{2}{*}{8} & + & $1 \cdot 28$ & $3 \cdot 45$ & 1.97 & $5 \cdot 90$ & $65 \cdot 0$ & $58 \cdot 5$ \\
\hline & Mean & 0.93 & $3 \cdot 13$ & 1.61 & 6.07 & $57 \cdot 2$ & $53 \cdot 35$ \\
\hline \multicolumn{2}{|c|}{ Standard error of mean } & $0 \cdot 130$ & $0 \cdot 193$ & $\mathbf{0} \cdot 187$ & 0.544 & $2 \cdot 746$ & 3.937 \\
\hline \multicolumn{2}{|c|}{$\begin{array}{l}\text { Significance of difference } \\
\text { group I-group II (P-value) }\end{array}$} & 0.85 & 0.07 & 0.012 & $0 \cdot 18$ & $<0.01$ & 0.01 \\
\hline
\end{tabular}

group than in the non-schizophrenic group, but it would be unwise, in view of the small number of cases, to generalize about this finding. The plasma noradrenaline concentration, too, is lower in the schizophrenic group, but the difference between the two groups is not significant.

The last two columns of Tables I and II show the concentrations of the two amines in the C.S.F. expressed as a percentage of their plasma concentrations. The means of the figures for adrenaline

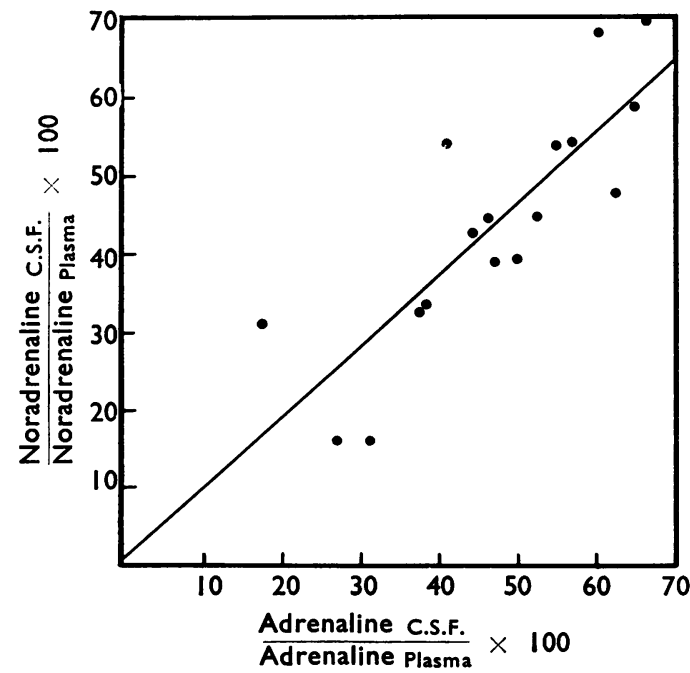

FIG. 1.-Regression of the ratio noradrenaline c.s.F./noradrenaline plasma on the ratio adrenaline c.s.F./adrenaline plasma. The diagonal line is the calculated linear regression. and noradrenaline are in fairly good agreement for each of the two groups, but there is a significant difference between the corresponding means of the two groups, not only in the case of adrenaline but also in the case of noradrenaline. The schizophrenic group has a significantly higher amine concentration in C.S.F. relative to the plasma concentration.

The percentage figures for adrenaline and noradrenaline are not always in good agreement in individual cases. In Fig. 1 the ratio adrenaline c.s.F./ adrenaline plasma $\times 100$ has been plotted against the corresponding ratio for noradrenaline, the results of both groups having been pooled for this purpose. The linear regression equation for this array is $y=0.95+0.915 \mathrm{x}$, and the standard error of the regression coefficient is $0 \cdot 154\left(t_{n=15}=5.94\right)$. There is thus a significant correlation between these ratios. Moreover, since the regression line goes through the origin and since its slope is not significantly different from 1 , there is statistical equality between the two ratios and the individual discrepancies have to be attributed to experimental error.

It also follows from adrenaline c.s.r./adrenaline plasma $=$ noradrenaline c.s.F./noradrenaline plasma that adrenaline c.S.F./noradrenaline c.S.F. $=$ adrenaline plasma/noradrenaline plasma, i.e., the ratio of adrenaline to noradrenaline is the same in C.S.F. as in plasma.

\section{Discussion}

Neither of the two groups from which the present data have been gathered can, in the nature of things, 
be regarded as strictly normal. The first group consists largely of epileptics, but it also includes a psychopath and a case of presenile dementia. The schizophrenic group comprises acute and chronic cases with predominantly paranoid, hebephrenic, or catatonic features. Three of these patients have had a prefrontal leucotomy. On the other hand, none of the specimens of C.S.F. on which the estimations were carried out was abnormal with regard to total number of cells, differential cell count, protein concentration, Pandy's and NonneApelt's tests for globulin, colloidal gold reaction, the Kahn test, and chloride and glucose concentrations. Since, in spite of considerable individual variation, the mean values for adrenaline are practically identical and those for noradrenaline are not significantly different in the two groups, they may provisionally be accepted as indicative of normal levels. These levels are considerably lower than in venous plasma, showing once again that C.S.F. must not be regarded as a mere ultrafiltrate of plasma, but as the product of an epithelium with specific secretory functions. The discrepancy between plasma and C.S.F. levels is, however, less marked than in the case of cortisone and hydrocortisone which occurs in C.S.F. in concentrations equivalent to 3 to $5 \%$ of their plasma concentrations (Baron and Abelson, 1954). The relatively higher concentration of adrenaline and noradrenaline in C.S.F. may be connected with their functions at the synapses of sympathetic tracts and with the fact that noradrenaline, at least, occurs in high concentration in certain parts of the central nervous system (Vogt, 1954).

The significance of the higher C.S.F./plasma distribution ratio in the schizophrenic group is difficult to assess. It is accounted for largely by a lower blood level rather than by a higher concentration in C.S.F. The permeability of the blood- brain barrier, as measured by the bromide test, tends to be decreased in schizophrenia (Walter, 1929) ; if the C.S.F. levels of adrenaline and noradrenaline were dependent on the same mechanism as the bromide level a lowering of the distribution ratio might have been expected.

\section{Summary}

The concentrations of adrenaline and noradrenaline in cerebrospinal fluid and plasma were determined concurrently in a group of nine patients with suspected organic brain lesions and in a group of eight chronic schizophrenics.

The mean C.S.F. concentrations in the two groups were found to be 0.90 and $0.93 \mu \mathrm{g}$. $/ 1$. respectively for adrenaline and 2.46 and $3.13 \mu \mathrm{g}$./1. respectively for noradrenaline. The differences between the groups are not significant.

The plasma adrenaline concentration was significantly lower in the schizophrenic group. Conversely, the C.S.F.-plasma distribution ratio was significantly higher in the schizophrenic group for both adrenaline and noradrenaline.

The C.S.F.-plasma distribution ratio is statistically equal for adrenaline and noradrenaline. The ratio of adrenaline/noradrenaline is therefore the same in plasma and in C.S.F., adrenaline accounting for approximately $25 \%$ of the sum of the amines.

The authors are indebted to Dr. R. Ström-Olsen for his interest and encouragement, to Mr. A. D. Bone and Mrs. N. Stephens for technical assistance and to Mr. T. C. Hall for the routine investigation of C.S.F. The work has been aided by a grant for technical assistance from the Medical Research Council.

\section{REFERENCES}

Baron, D. N.. and Abelson, D. (1954). Nature, 173, 174.

Vogt, M. (1954). J. Physiol, Lond., 123, 451.

Walter, F. K. (1929). Die Blut-Liquorschranke. Thieme, Leipzig. Weil-Malherbe, H., and Bone, A. D. (1952). Biochem. J., 51, 311 $\longrightarrow$ - - (1953). Lancet, 1, 974. 